\title{
Penataan Kawasan Wisata Lakkang Berbasis Masyarakat
}

\author{
Ihsan $^{1 *}$, Abdul Rachman Rasyid ${ }^{1}$, Ananto Yudono ${ }^{1}$, Shirly Wunas ${ }^{1}$, Slamet Trisutomo ${ }^{1}, \mathrm{M}$. \\ Yamin Jinca ${ }^{1}$, Mukti Ali $^{1}$, Mimi Arifin ${ }^{1}$, Arifuddin Akil ${ }^{1}$, Wiwik Wahidah Osman ${ }^{1}$, Yashita K. \\ Dewi $^{1}$, Sri Aliah Ekawati ${ }^{1}$, Muh. Fathien Azmy ${ }^{1}$, Gafar Lakatupa ${ }^{1}$, Sri Wahyuni ${ }^{1}$, Laode Muh. Asfan \\ Mujahid $^{1}$ \\ Departemen Perencanaan Wilayah dan Kota, Fakultas Teknik, Universitas Hasanuddin ${ }^{1}$ \\ ace.ihsan@gmail.com ${ }^{1 *}$
}

\begin{abstract}
Abstrak
Pariwisata di Indonesia terdiri berbagai jenis objek wisata yang hingga kini menjadi daya tarik tersendiri bagi wisatawan baik domestik maupun mancanegara. Sebuah kawasan wisata membutuhkan penataan tersendiri agar wisatawan dapat tertarik untuk mengunjungi lokasi tersebut. Penataan sebuah kawasan strategis dan menarik menjadi destinasi wIsata telah banyak dijumpai di berbagai daerah. Sebagian besar lokasi tersebut ditata berdasarkan keinginan dan harapan dari masyarakat yang bermukim di kawasan tersebut. Pentingnya peran masyarakat lokal dalam pengembangan destinasi pariwisata berkelanjutan telah mendorong munculnya tren baru pengembangan pariwisata yang berbasis masyarakat. Hal ini juga dilakukan di kawasan kelurahan Lakkang yang merupakan salah satu lokasi yang memiliki potensi pariwisata di Kota Makassar. Peneltian ini bertujuan untuk melihat menjelaskan penataan kawasan Lakkang menjadi kawasan wisata yang berbasis pada perspektif masyarakat. Teknik pengumpulan data dilakukan dengan observasi eksisting kawasan, review data atau dokumen terkait kawasan dan wawancara yang dilakukan dalam kegiatan Focus Group Discussion (FGD) bersama masyarakat di kawasan delta Lakkang. Teknik analisis kegiatan pengabdian ini menggunakan analisis deskriptip kualitatif dan spasial. Hasil pengabdian ini menunjukkan eksisting potensi wisata di delta Lakkang, serta penggunaan konsep ekowisata sebagai konsep yang dapat menguntungkan tidak hanya masyarakat tetapi juga kelestarian kawasan wisata di kelurahan Lakkang.
\end{abstract}

Kata Kunci: Wisata; Masyarakat; Diskusi Fokus Grup; Ekowisata; Lakkang.

\begin{abstract}
Tourism in Indonesia consists of various types of tourist objects which until now have become the main attraction for both domestic and foreign tourists. A tourist area needs its own arrangement so that tourists can be interested in visiting that location. The arrangement of a strategic and attractive area to become a tourist destination has been found in many regions. Most of these locations are arranged based on the wishes and expectations of the people who live in the area. The importance of the role of local communities in the development of sustainable tourism destinations has encouraged the emergence of new trends in community-based tourism development. This is also done in the area of Lakkang Village, which is one of the locations that has tourism potential in Makassar City. This research aims to explain the arrangement of the Lakkang area into a tourist area based on a community perspective. Data collection techniques are carried out by observing the existing area, reviewing data or documents related to the area and interviews conducted in Focus Group Discussion (FGD) activities with the community in the Lakkang delta area. The analysis technique of this research uses descriptive qualitative and spatial analysis. The results of this study indicate the existing tourism potential in the Lakkang delta, as well as the use of the ecotourism concept as a concept that can benefit not only the community but also the preservation of the tourist area in Lakkang village.
\end{abstract}

Keywords: Tourism; Community; Focus Group Discussion; Ecotourism; Lakkang.

\section{Pendahuluan}

Aktivis komunitas/masyarakat berjuang untuk mendapatkan setidaknya beberapa kendali atas proses pembaruan pada sistem perkotaan, dan seiring waktu pemerintah dipaksa untuk memasukkan warga dalam proses perencanaan sebuah kawasan (Peterman, 2000). Masyarakat di 
dalam destinasi pariwisata yang kemudian disebut dengan masyarakat lokal mempunyai potensi berupa beragam aktivitas yang dapat dikreasikan menjadi produk pariwisata. Budaya lokal, tinggalan masyarakat, serta festival menyediakan keunikan dan sesuatu yang baru dari perspektif wisatawan. Masyarakat dengan pengetahuan dan kebijakan lokal akan lebih memahami produk pariwisata yang dikembangkan serta dampak yang ditimbulkan, dibandingkan dengan masyarakat dari luar destinasi pariwisata. Masyarakat lokal juga mempunyai kontribusi dalam upaya perencanaan kawasan, tidak hanya dalam mempromosikan produk destinasi pariwisata namun juga dalam keseluruhan proses penataan wisata, karena masyarakat lokal adalah komponen utama pembentuk citra atau image destinasi pariwisata (Adikampana, 2017).

Kegiatan pengabdian kepada masyarakat yang dilakukan dalam lingkup penerapan Ipteks bagi Wilayah (IbW) yang akan dilaksanakan dalam lingkup wilayah kelurahan Lakkang kecamatan Tallo, Kota Makassar. Tujuan kegiatan ini difokuskan pada aspek penataan kawasan wisata di Kelurahan Lakkang dengan berbasis pada komunitas/masyarakat.

Kawasan Delta Lakkang di kelurahan Lakkang memiliki potensi pariwisata yang meliputi potensi alam, potensi sosial budaya, serta potensi sejarah. Penentuan daerah Lakkang sebagai desa wisata untuk kawasan Delta Lakkang berlandaskan pada Peraturan Daerah Kota Makassar tentang Rencana Induk Pengembangan Pariwisata Daerah (RIPPDA) tahun 2015-2035. Berdasarkan Peraturan Daerah (PERDA) Kota Makassar nomor 4 tahun 2015 tentang Rencana Tata Ruang Wilayah (RTRW) Kota Makassar tahun 2015-2034 tentang Rencana Pola Ruang, Kecamatan Tallo memiliki kawasan yang diperuntukkan sebagai kawasan pariwisata yang meliputi kawasan pariwisata budaya, kawasan pariwisata alam dan kawasan pariwisata buatan.

Kelurahan Lakkang merupakan suatu kampung yang sejuk ditengah Kota Makassar yang memiliki beberapa bunker peninggalan Jepang, dan dikelilingi beberapa mangrove, serta terdapat rumah-rumah tradisional. Daerah ini juga biasanya digunakan pengunjung untuk melakukan beberapa kegiatan. Lakkang juga memiliki nilai keunikan budaya dengan pola hidup tradisional yang perlu dilestarikan dan fungsi daya dukung lingkungan hidup di Kota Makassar. Delta Lakkang masuk dalam daftar Kawasan Strategis Pariwisata Daerah IV (KSPD IV), program pelaksanaan strategi yang akan dilakukan berupa Historical dan Ekowisata Creativity Centre (RIPPDA Kota Makassar 2015- 2035).

Kawasan wisata Lakkang merupakan salah satu lokasi atau spot wisata di Kota Makassar, namun belum ditangani dengan baik. Karakteristik ekologi kawasan wisata yang mengalami degradasi seperti masalah lingkungan delta dan kurangnya penataan kawasan wisata serta penataan sarana dan prasarana wisata. Selain itu, peran masyarakat dalam partisipasi perencanaan masih minim dilakukan. Untuk itulah penataan kawasan wisata di Kelurahan Lakkang dilakukan sebagai salah satu bentuk kegiatan pengabdian kepada masyarakat

\section{Latar Belakang Teori}

Pariwisata dapat dianggap sebagai sebuah sistem yang memungkinkan wisatawan menikmati objek dan daya tarik wisata (ODTW) pada suatu wilayah. Berdasarkan UU (2009), tentang Kepariwisataan, destinasi pariwisata adalah kawasan geografis yang berada dalam satu atau lebih wilayah administratif yang di dalamnya terdapat daya tarik wisata, fasilitas umum, fasilitas pariwisata, aksesibilitas, serta masyarakat yang saling terkait dan melengkapi terwujudnya kepariwisataan. Hal ini memperlihatkan masyarakat sebagai salah satu komponen pelengkap dalam pariwisata itu sendiri. 
Pariwisata berbasis masyarakat didefinisikan sebagai partisipasi masyarakat dalam pembangunan pariwisata. Dalam hal ini, partisipasi masyarakat dapat dilakukan dengan dua cara yaitu: ikut terlibat dalam proses pengambilan keputusan dan pembagian manfaat pariwisata. (Timothy \& Boyd, 2003). pariwisata merupakan sebuah "community industry", sehingga keberlanjutan pembangunan pariwisata sangat tergantung dan ditentukan oleh penerimaan dan dukungan masyarakat terhadap pariwisata. Implikasi pariwisata sebagai sebuah industri masyarakat adalah adanya kepastian bagi masyarakat untuk berpartisipasi dalam pengembangan pariwisata. (Murphy, 1985). Partisipasi dalam pengambilan keputusan berarti masyarakat mempunyai kesempatan untuk menyuarakan harapan, keinginan dan kekhawatirannya dari pembangunan pariwisata, yang selanjutnya dapat dijadikan masukan dalam proses perencanaan pariwisata (Adikampana, 2017).

Penataan wisata di kawasan Lakkang ini juga disesuaikan atau dibuat sejalan dengan program dalam RIPPDA Kota Makassar 2015- 2035 tentang program pelaksanaan strategi Historical dan Ekowisata Creativity Centre di kawasan Lakkang yang merupakan salah satu kawasan strategis pariwisata di Kota Makassar. Hal ini diwujudkan dengan konsep ekowisata dalam penataan wisata di kawasan delta Lakkang. Definisi ekowisata yang pertama diperkenalkan oleh organisasi The Ecotourism Society sebagai berikut: Ekowisata adalah suatu bentuk perjalanan wisata ke area alami yang dilakukan dengan tujuan mengkonservasi lingkungan dan melestarikan kehidupan dan kesejahteraan penduduk setempat. Semula ekowisata dilakukan oleh wisatawan pecinta alam yang menginginkan di daerah tujuan wisata tetap utuh dan lestari, di samping budaya dan kesejahteraan masyarakatnya tetap terjaga. Hal ini menunjukkan konsep ekowisata tidak hanya tertuju pada pelestarian alam tetapi juga fokus pada masyarakat sekitarnya.

Perencanaan ekowisata harus memperhatikan konservasi sumber daya alam, menjamin pelibatan masyarakat lokal, meningkatkan pengalaman, mencakup kegiatan kegiatan yang bertanggung jawab, dan mendorong usaha skala kecil yang produktif. Perencanaan yang dilakukan harus komprehensif dan 3amboo3s dengan 3amboo3se kompleksitas 3amboo pariwisata itu sendiri (Asmin, 2018).

\section{Metode}

\subsection{Jenis Pengabdian}

Jenis pengabdian ini menggunakan pendekatan persuasif melalui metode kualitatif berupa grup diskusi atau Forum Group Discussion (FGD).

\subsection{Teknik analisis}

Teknik analisis yang digunakan yaitu analisis deskriptif dan analisis spasial dan nantinya digunakan pada saat FGD.

\subsection{Metode Pengumpulan data dan sharing}

Metode pengumpulan data yang dilakukan pada kawasan wisata di kelurahan Lakkang adalah observasi (kondisi eksisting kawasan), review dokumen terkait kawasan wisata Lakkang, dan wawancara. Data capaian selanjutnya digunakan dalam sharing dan transfer knowledge kepada masyarakat. 


\section{Hasil dan Diskusi}

\subsection{Karakteristik kawasan wisata di Kekurahan Lakkang}

Secara geografis, Kelurahan Lakkang merupakan satu dari 15 kelurahan yang ada di Kecamatan Tallo Kota Makassar. Kelurahan ini berada pada delta yang terbentuk dari endapan sungai Tallo. Luas Kelurahan Lakkang yatu $1,15 \mathrm{~km}^{2}$ dengan ketinggian $<500$ mdpl. Pulai Lakkang ini diapit oleh tiga sungai, yakni Sungai Tallo, Sungai Pampang dan sungai yang melintasi Universitas Hasanuddin (UNHAS). Ketiga sungai ini membuat Pulau Lakkang terkesan tak terlihat dan jarang diketahui oleh masyarakat umum Kota Makassar, untuk sampai di pulau ini, wisatawan dapat memilih memulai perjalanan di beberapa dermaga belakang kampus Unhas, dermaga di samping Tol Ir. Sutami, dermaga di Kelurahan Pampang dan Dermaga di Kelurahan Tallo (Gambar 1).

Berdasarkan BPS Kota Makassar Tahun 2018, jumlah penduduk di Kelurahan Lakkang berdasarkan data terakhir yaitu 975 jiwa dengan jumlag rumah tangga sebanyak 238. Kepadatan penduduk sebanyak 848 per $\mathrm{km}^{2}$. Banyaknya penduduk berdasarkan jenis kelamin yaitu laki-laki sebanyak 494 jiwa dan perempuan sebanyak 481 jiwa dengan seks ratio sebesar 102,70. Perpindahan penduduk yang 4amboo dan pindah dari Pulau Lakkang terbilang sangat kecil diantara 14 kelurahan lainnya yang ada di Kecamatan Tallo yaitu sekitar 2 orang dalam satu tahun pada tahun 2018. Masih terdapat 55 kepala kelurga yang masuk dalam kategori prasejahtera. Umumnya, masyarakat yang bermukim dalam kawasan ini berprofesi sebagai nelayan. Beberapa yang lain berprofesi sebagai wirausahawan, petani, serta pegawai di Kota Makassar.

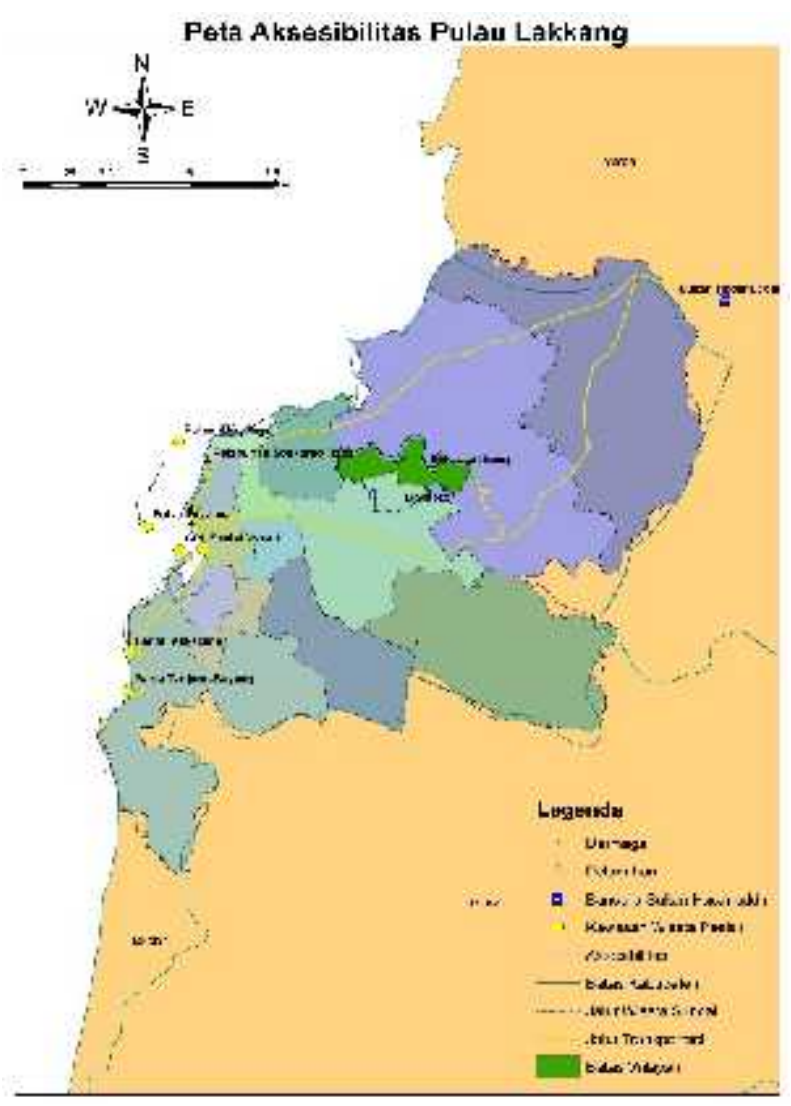

Gambar 1. Peta aksesibilitas di kawasan Lakkang 
Untuk aksesibilitas, satu-satunya transportasi yang menghubungkan Lakkang dengan Kota Makassar yaitu dengan jalur perairan. Terdapat tiga dermaga yang biasa digunakan masyarakat setempat maupun pendatang, yaitu dermaga Kera-Kera di Universitas Hasanuddin, dermaga di dekat Jalan Tol Reformasi, dan dermaga di Kelurahan Pampang. Diperlukan biaya sekitar lima hingga 15 ribu rupiah untuk menggunakan perahu penyeberangan tersebut. Perahu tersebut juga dapat memuat kendaraan seperti motor atau sepeda untuk menyeberang dengan biaya lima ribu rupiah per kendaraan. Sarana yang digunakan dalam penyeberangan cukup unik. Perahu yang digunakan dikenal dengan nama Pincara' atau dua perahu yang disatukan sehingga tergabung menjadi satu perahu yang lebih besar denah lokasi pengabdian (Gambar 2).

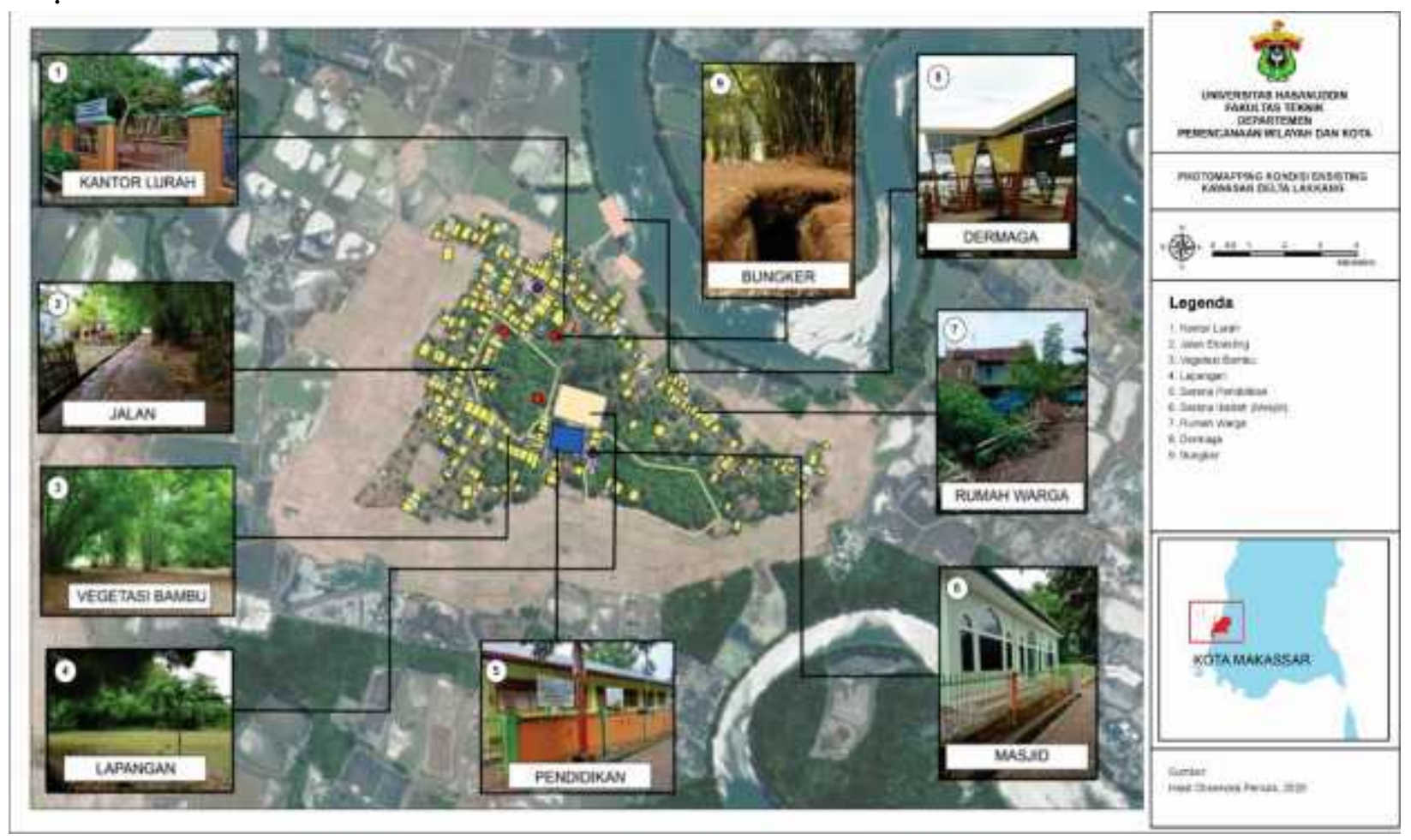

Gambar 2. Photomapping kondisi eksisting kawasan delta Lakkang

\subsection{Kegiatan Focus Group Discussion sebagai ajang partisipasi masyarakat dalam perencanaan wisata.}

Focus Group Discussion, atau disingkat FGD yang berarti Diskusi Kelompok Terarah, adalah salah satu metode komunikasi pembangunan yang dipopulerkan oleh para ahli pemberdayaan masyarakat dan Participatory Rural Approach (PRA). FGD makin akrab terdengar di telinga seiring dengan dicanangkannya paradigma pembangunan partisipatif (Fardiah, 2005). Penataan kawasan wisata di kelurahan Lakkang yang berbasis kepada masyarakat ini juga melakukan kegiatan FGD sebagai salah satu upaya pelibatan masyarakat dalam perencanaan kawasan wisata. Metode focus group discussion (FGD) dilakukan untuk mengidentifikasi potensi dan permasalahan dari masyarakat local (Gambar 3). 


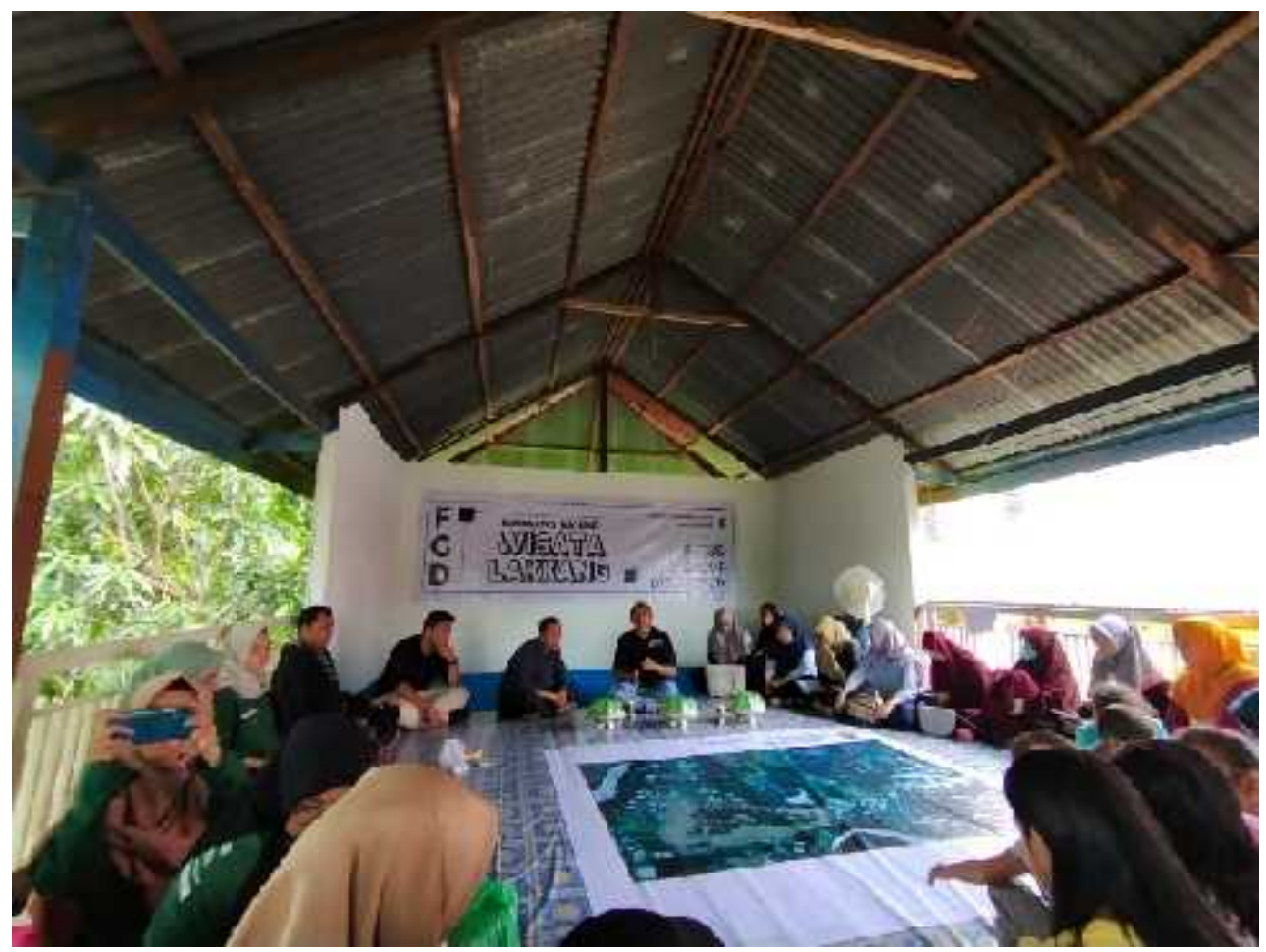

Gambar 3. Kegiatan FGD bersama masyarakat di kawasan wisata Lakkang

Berdasarkan hasil kegiatan FGD, permasalahan yang terjadi di Pulau Lakkang yaitu Air bersih susah di dapatkan, Air sumur bor rusak atau tidak dapat digunakan, Masih kurangnya WC umum atau tempat pembuangan sementara untuk wisatawan (RT 01 RW 01), Minimnya drainase di Lakkang menjadi ke khawatiran masyarakat, Kurangnya lampu jalan/lampu Lorong,Banyak jalanan rusak yang belum di renovasi ulang (RT 01 RW 02), Dermaga pulau Lakkang butuh WC umum, Banker perlu dibersihkan dan dirawat kembali untuk menarik wisatawan, Kurangnya tempat sampah untuk setiap rumah masyarakat di Lakkang, Bank sampah tidak beroperasi dengan baik, Banyak sampah berserakan dan 6amboo kering, dan renovasi dermaga Lakkang.

Selain permasalahan juga teridentifikasi potensi wisata. Delta Lakkang memiliki beberapa objek yang memiliki daya 6ambo wisata serta pendukung kepariwisataan. Kondisi alamiah yang terdapat di Delta Lakkang menjadi nilai jual tersendiri, apalagi wilayah ini berada di pusat Kota Makassar dengan beragam aktivitas metropolitannya sehingga Delta Lakkang memiliki karakteristik yang berbeda dengan wilayah yang mengelilinginya. Beberapa objek yang memiliki daya tarik tersendiri dan terdapat dalam kawasan ini diantaranya adalah hutan bambu, Wisata Susur Pesisir Lakkang, sawah dan tambak, serta wisata sejarah dan kebudayaan local peta potensi (Gambar 4). 


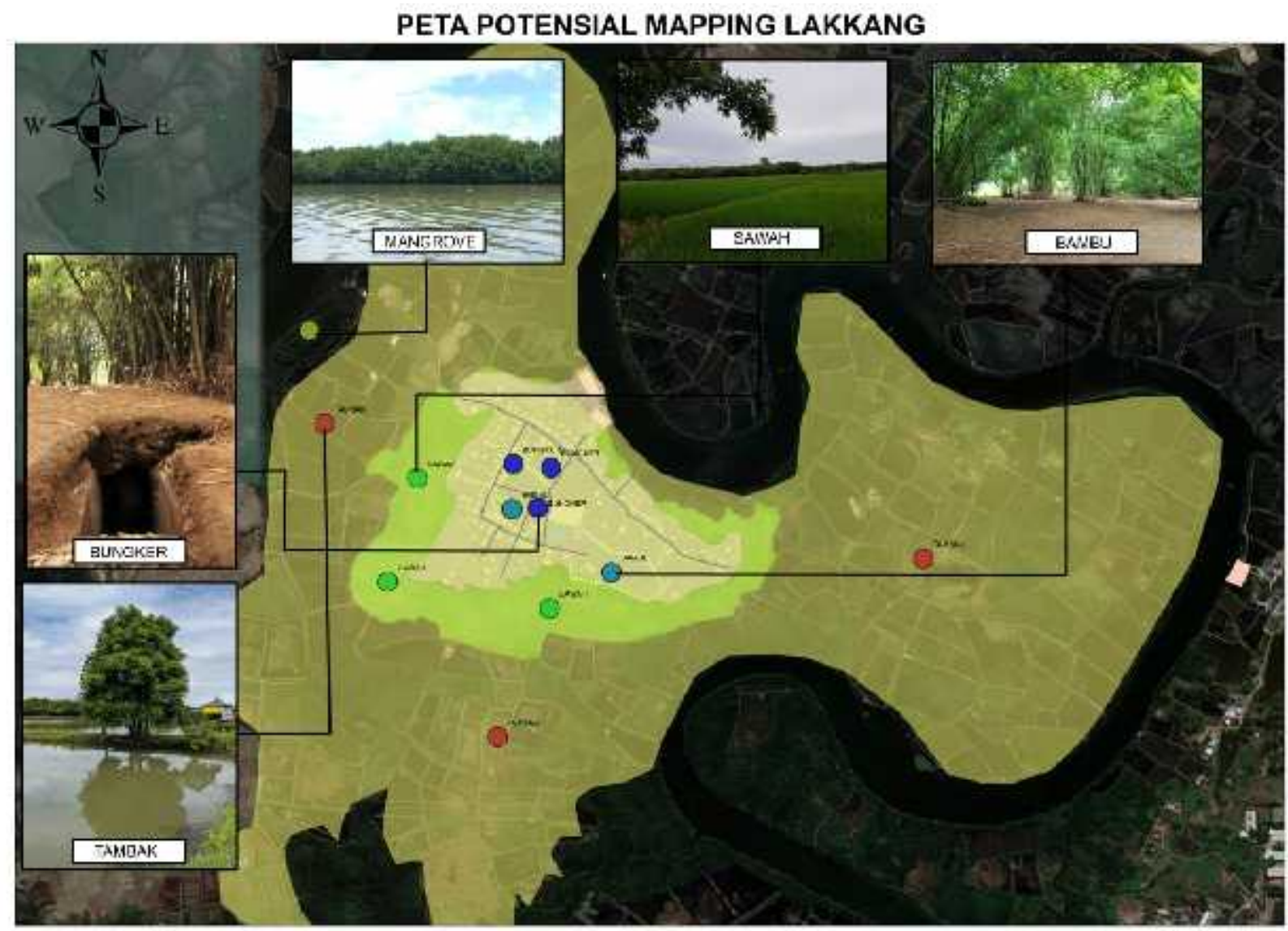

Gambar 4. Photomapping kondisi eksisting kawasan delta Lakkang

\subsection{Konsep perencanaan wisata di Kelurahan Lakkang}

Konsep ekowisata dalam perencanaan wisata di kelurahan Lakkang tidak lepas dari pelibatan masyarakat setempat. Pelibatan masyarakat pada kegiatan awal dilakukan dengan melakukan FGD bersama masyarakat setempat. Selain itu, arahan konsep ekowisata yang dirumuskan juga sejalan dengan basis perencanaan wisata kegiatan ini yaitu berbasis pada masyarakat konsep pengarahan secara terperinci (Tabel 1) dan desain yang didiskusikan (Gambar 5 dan Gambar 6).

Tabel 1. Arahan Konsep Ekowisata di Lakkang

\begin{tabular}{|l|l|l|}
\hline No & \multicolumn{1}{|c|}{ Komponen Ekowisata } & \multicolumn{1}{c|}{ Arahan konsep ekowisata di Lakkang } \\
\hline 1 & $\begin{array}{l}\text { Kontribusi terhadap konservasi } \\
\text { biodiversitas }\end{array}$ & $\begin{array}{l}\text { Kerjasama dengan pihak dinas terkait konservasi dan } \\
\text { budidaya serta pihak Lembaga dan universitas dalam } \\
\text { kegiatan pelestarian Kawasan sekitar delta (penanaman } \\
\text { mangrove, dsb) }\end{array}$ \\
\hline 2 & $\begin{array}{l}\text { Keberlanjutan kesejahteraan } \\
\text { masyarakat lokal }\end{array}$ & $\begin{array}{l}\text { Pengadaaan guide dari tenaga masyarakat setempat, } \\
\text { souvenir lokal, akomodasi lokal, penyediaan pelatihan } \\
\text { pembuatan kerajinan tangan dan produk ekonomi } \\
\text { berdasarkan sumber daya yang tersedia di Kawasan } \\
\text { setempat. }\end{array}$ \\
\hline 3 & $\begin{array}{l}\text { Mencakup interpretasi/pengalaman } \\
\text { pembelajaran }\end{array}$ & $\begin{array}{l}\text { Pembuatan signage, Pembangunan Dermaga Terapung, } \\
\text { Pembuatan board informasi di titik-titik objek wisata, }\end{array}$ \\
\hline
\end{tabular}




\begin{tabular}{|l|l|l|}
\hline No & \multicolumn{1}{|c|}{ Komponen Ekowisata } & \multicolumn{1}{c|}{ Arahan konsep ekowisata di Lakkang } \\
\hline 4 & $\begin{array}{l}\text { Melibatkan tindakan bertanggung } \\
\text { jawab dari wisatawan dan industri } \\
\text { pariwisata }\end{array}$ & $\begin{array}{l}\text { Wembangunan restoran apung } \\
\text { keterlibatan multi pihak, dan menghindari eksploitasi } \\
\text { atraksi alam dan budaya yang rentan }\end{array}$ \\
\hline 5 & $\begin{array}{l}\text { Berkembangnya usaha } \\
\text { skala kecil }\end{array}$ & $\begin{array}{l}\text { Pembentukan usaha produktif dengan menggandeng } \\
\text { ibu-ibu PKK warga sekitar. }\end{array}$ \\
\hline 6 & $\begin{array}{l}\text { Menggunakan sumber daya } \\
\text { baru dan terbarukan }\end{array}$ & $\begin{array}{l}\text { Penggunaan energi lokal, fasilitas yang } \\
\text { ramah lingkungan, dan introduksi teknologi ramah } \\
\text { lingkungan }\end{array}$ \\
\hline 7 & $\begin{array}{l}\text { Fokus pada partisipasi masyarakat, } \\
\text { kepemilikan, dan kesempatan usaha }\end{array}$ & $\begin{array}{l}\text { Menggunakan tenaga pendamping/ fasilitator, } \\
\text { membentuk Lembaga multipihak, memberikan peluang } \\
\text { sebagai tour operator dan pengelola kawasan, } \\
\text { masyarakat sebagai agen perubahan, jaminan peran } \\
\text { tokoh, dan keberpihakan politik }\end{array}$ \\
\hline
\end{tabular}
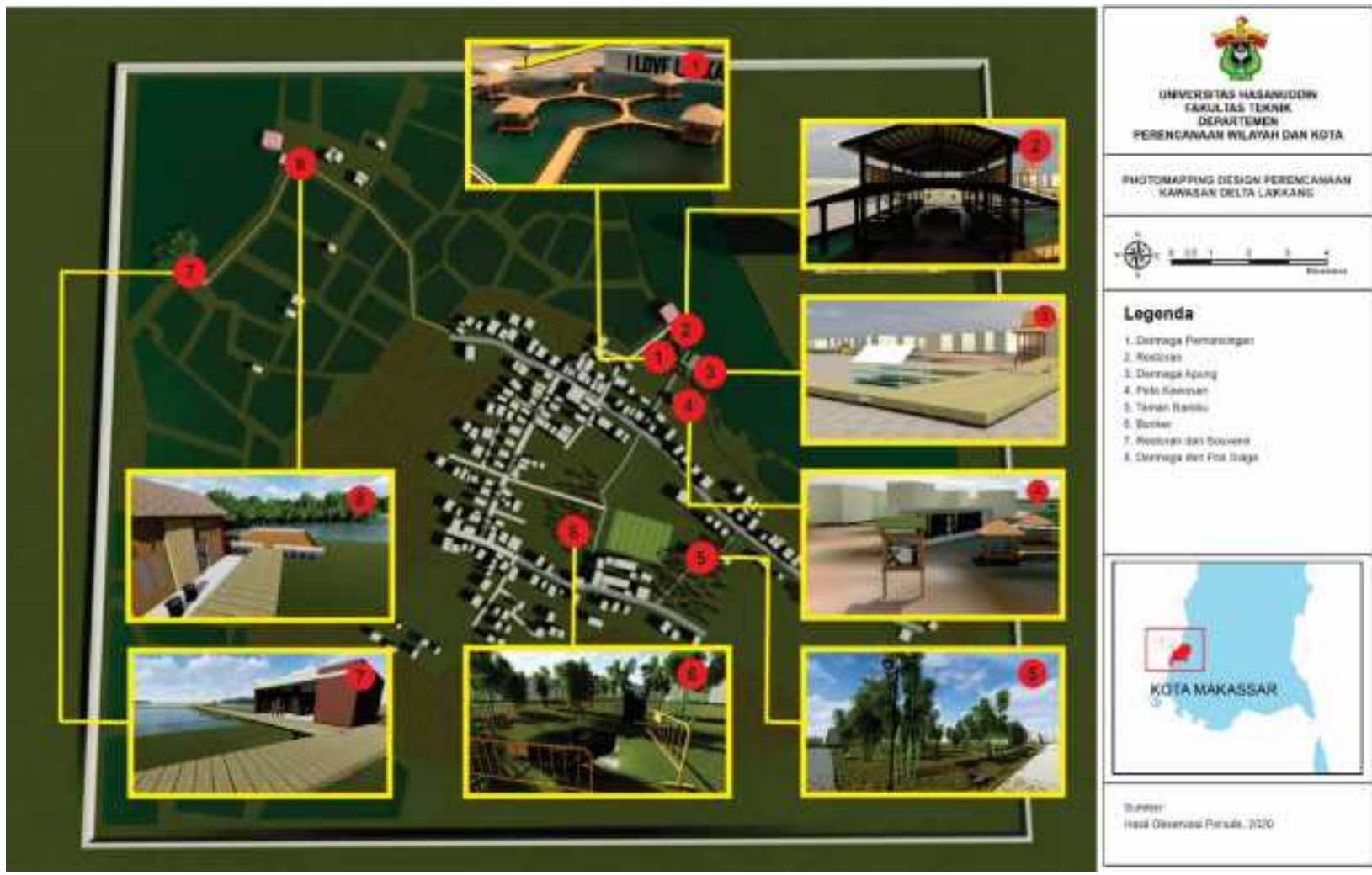

Gambar 5. Photomapping desain perencanaan delta Lakkang 

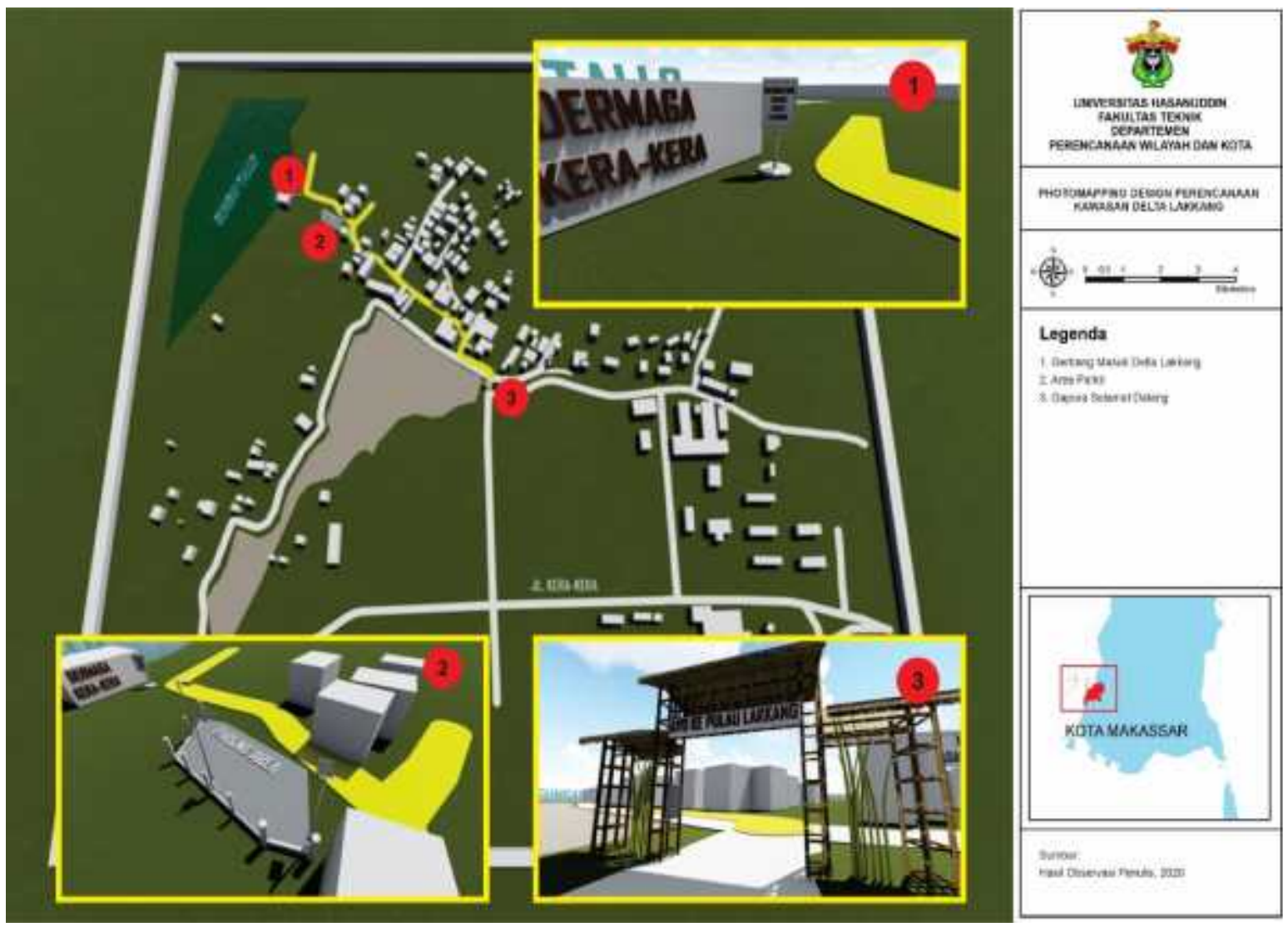

Gambar 6. Photomapping desain perencanaan delta Lakkang (2)

\section{Kesimpulan}

Kegiatan pengabdian kepada masyarakat yang dilakukan di kawasan delta Lakkang berupa penataan kawasan ini dilakukan berdasarkan atau berbasis kepada komunitas masyarakat sekitar. Hal ini ditunjukkan dengan pengadaan kegiatan FGD sebagai ajang pelibatan masyarakat dalam proses perencanaan wisata, juga penggunaan konsep ekowisata yang di dalamnya sarat akan pelibatan masyarakat dalam seluruh kegiatan pariwisata mulai dari produk, aksesibiltas transportasi hingga pelestarian kawasan wisata.

\section{Ucapan Terima Kasih}

Ucapan terima kasih kepada Lurah Lakkang dan jajaran staf Kelurahan Lakkang yang telah memfasilitasi pelaksanaan kegiatan ini serta turut mendorong keaktifan masyarakat dalam kegiatan ini sehingga kegiatan pengabdian kepada masyarakat ini dapat terselesaikan. Tak lupa kepada juga terima kasih kepada seluruh masyarakat kelurahan Lakkang yang sangat kooperatif dalam penyelesaian kegiatan ini.

\section{Daftar Pustaka}

Peterman, w., (2000). Neighborhood planning and community-based development. California:

Sage Publication Inc.

Adikampana, I. M., (2017). Pariwisata Berbasis Masyarakat. Bali: Cakra Press. 
UU, (2009). Kepariwisataan RIPPDA Kota Makassar 2015- 2035, Undang-undang No. 10 tahun 2009.

Timothy, D. J., \& Boyd, S. W. (2003). Heritage Tourism. England: Pearson Education.

Murphy, P. E., (1985). Tourism A Community Approach. New York: Methuen.

Asmin, F., (2018). Ekowisata dan Pembangunan Berkelanjutan: Dimulai dari Konsep Sederhana. Bogor: reserachgate https://www.researchgate.net/publication/323309174. 